\title{
Enkorten - A Potential Drug for the Treatment of Rheumatoid Arthritis
}

\author{
Nedžad Mulabegović et al.* \\ Medical Faculty University of Sarajevo Institute of Pharmacology, \\ Clinical Pharmacology and Toxicology \\ Bosnia and Herzegovina
}

\section{Introduction}

Enkorten is a new potential drug for the treatment of rheumatoid arthritis, with an immunomodulatory and anti-inflammatory effect. It is a combination of two peptide components of endogenous origin: methionine-enkephalin of $5 \mathrm{mg}$ and tridecactide of $1 \mathrm{mg}$ (Picture 1 and 2). According to the chemical structures, these components correspond to amino acid sequences of the neuropeptide precursor proopiomelanocortin.

\begin{tabular}{|ll|}
\hline Generic name: & tridecactide \\
Chemical name: & (des-acetyl)- $\alpha$-MSH-(de-amid) - $\alpha$-MSH \\
Gross formula: & $\mathrm{C}_{75} \mathrm{H}_{106} \mathrm{~N}_{20} \mathrm{O}_{19} \mathrm{~S}$ \\
Molecular weight: & 1623.85 \\
Amino acid sequence: & H-Ser-Tyr-Ser-Met-Glu-His-Phe-Arg-Trp-Gly-Lys-Pro-Val-OH \\
\hline
\end{tabular}

Picture 1. Chemical characteristics of tridecactide

\begin{tabular}{|ll|}
\hline Generic name: & met-enkephalin 1-5 adrenorphin \\
Gross formula: & $\mathrm{C}_{27} \mathrm{H}_{35} \mathrm{~N}_{5} \mathrm{O}_{7} \mathrm{~S}$ \\
Molecular weight: & 573.67 \\
Amino acid sequence: & H-Tyr-Gly-Gly-Phe-Met-OH \\
\hline
\end{tabular}

Picture 2. Chemical characteristics of met-enkephalin

The holder of effects of the tested combination is alpha 1-13 corticotrophin-tridecactide (ACTH 1-13), composed of 13 amino acids, identical to the amino acid sequence of the alpha-melanostimulating hormone $(\alpha-\mathrm{MSH})$, but without the acetyl and amide ending. Some studies suggest that $\alpha-\mathrm{MSH}$ is synthesized in the pituitary, other parts of the CNS, the placenta, and some endocrine organs - especially the adrenal, the skin and the gastrointestinal tract (Star et al, 1995; Catania et al, 2000). The presence of this neuropeptide in the mucous membrane of the gastrointestinal tract and keratinocytes of the skin suggests

\footnotetext{
* Jasna Kusturica, Maida Todić-Rakanović, Mirjana Mijanović, Fahir Bečić, Asija Začiragić, Selma Škrbo, Lejla Burnazović-Ristić, Aida Kulo and Svjetlana Loga-Zec Medical Faculty University of Sarajevo Institute of Pharmacology, Clinical Pharmacology and Toxicology, Bosnia and Herzegovina
} 
that it is a component of natural immunity (Catania et al, 2000a). The supposed connection between alpha-MSH and immune processes is confirmed by the clinical data on changes of its plasma level under certain pathological conditions (Lipton and Catania, 1997; Lipton et al, 2000). An increased concentration of $\alpha-\mathrm{MSH}$ has been recorded in patients with an acute myocardial infarction who received thrombolytic therapy, probably as an endogenous antiinflammatory response. This peptide has been identified in the synovial fluid of patients with rheumatoid arthritis (Star et al, 1995) and it is believed that the inflammation and joint destruction in this disease occur due to imbalances of production of proinflammatory and anti-inflammatory cytokines such as $\alpha-\mathrm{MSH}$. A higher concentration of $\alpha-\mathrm{MSH}$ has been found in patients suffering from arthropathy accompanied by heavy inflammation (Lipton et al, 2000). Since $\alpha-\mathrm{MSH}$ is a natural modulator peptide, its concentration is subject to intensive control to avoid excessive inhibition of the immune response. It is assumed that the increased concentration of peptides leads to downregulation of receptors in cells, which could explain the biphasic curve of the anti-inflammatory effects $\alpha-\mathrm{MSH}$ (Catania et al, 2000).

The other component contained in the drug is met-enkephalin, which belongs to a group of endogenous opioid peptides, widely distributed in the CNS. All opioid peptides contain one or more copies of the simplest opioid peptides: methionine-enkefalin (tyrosine-glycineglycine-phenylalanine-methionine) and leucine-enkephalin (tyrosine-glycine-glycinephenylalanine-leucine) (Janković, 1991). They participate in, and modulate neurotransmission. Opioid peptides also act as growth factors that control proliferation and differentiation of cells and may participate in the process of wound healing, tissue regeneration and immune response. Enkephalins show antidepressant, antianxiety and anticonvulsive effects. They are produced in the adrenal and the hypothalamus. Metenkephalin belongs to a group of enkephalins that are involved in transmitting signals in the nervous system, intestines, endocrine glands, bronchial tree, lymphatic and other tissues (Štambuk et al, 1996). The highest concentrations are present in the core of adrenal, hypothalamus, autonomic ganglia and the gastrointestinal tract (Janković, 1991).

Met-enkephalin as an inhibitory peptide modulates the proliferation and migration of cells, as well as the organization of tissues during development, homeostatic cell renewal, wound healing, angiogenesis, and in malignant neoplasms (Zagon et al, 2000). Physiologically, enkephalins have a signalling function in the nervous system, intestine, endocrine glands, bronchial tree, cardiovascular system, lymphatic and other tissues, and participate in the regulation of haematopoiesis (Štambuk et al, 1996). It is assumed that they participate in maintaining homeostasis of the organism exposed to stress (Mulabegović et RakanovićTodić, 2008).

\section{The place and importance of $\alpha-\mathrm{MSH}$ and met-enkephalin in immunomodulation}

Immunomodulatory effects of a combination of $\alpha-\mathrm{MSH}$ and met-enkephalin involve several mechanisms that support the modern trend in the development of new anti-inflammatory drugs. The method of selective immunomodulation using peptides has only recently been used in immune-mediated diseases and malignant neoplasm. Immunomodulation with antigens and peptides is directed towards achieving a satisfactory long-term remission without the occurrence of toxic side effects typical for immunosuppressive drugs. It is based on two approaches: the first approach is to block the initial activation of antigen recognition of autoreactive T cells, while the second is based on downregulation of specific antigenic 
inflammatory response of $\mathrm{T}$ cells through the activation of regulatory physiological mechanisms (Štambuk et al, 1997).

Until recently it was thought that the immune/inflammatory reaction develops exclusively in the periphery. Today it is known that the nervous, endocrine and immune systems are interconnected, and that they communicate by signals that are transmitted through neuropeptides. In this way, central neurogenic influences can either enhance or modulate the peripheral response, so by analogy the treatment of inflammatory reactions could be improved by the influence of the proinflammatory signals in the central nervous system. Thus, Catania et al. (1999) suggest that one of these strategies could be based on the action of $\alpha-\mathrm{MSH}$.

In the past several years, particular attention has been given to the anti-inflammatory effects of this peptide, as a result of the introduction of $\alpha-\mathrm{MSH}$ and related peptides in clinical practice for the treatment of inflammatory diseases (Getting, 2006). Undoubtedly, $\alpha-\mathrm{MSH}$, administered systemically or locally, expresses strong anti-inflammatory effects. Antiinflammatory effects of this peptide are mediated by direct effects on cells of the immune system, as well as by indirect effects that are achieved by changing the function of nonresident immune cells of peripheral tissues (Luger and Brzoska, 2007).

Three basic mechanisms of $\alpha-\mathrm{MSH}$ anti-inflammatory action can be distinguished: direct effects through melanocortin receptors on cells in the periphery (monocytes/macrophages and neutrophils); effects on glial cells; and descendent anti-inflammatory effects through melanocortin receptors on neurons (Lipton et al, 2000). These mechanisms of action correspond to the concept of neuroimmunomodulation in which nerves, endocrine and immune systems are independent networks that mutually communicate through soluble mediators such as cytokines and neuropeptides.

Multiple anti-inflammatory effects that $\alpha-\mathrm{MSH}$ has have been identified in various in vitro systems of cell cultures. Studies of anti-inflammatory effects of $\alpha-\mathrm{MSH}$ on cellular level were primarily concentrated on the issue whether and to what degree $\alpha-\mathrm{MSH}$ suppresses the production of pro-inflammatory cytokines. In this respect, several studies have shown that treatment with $\alpha-\mathrm{MSH}$ results in significant downregulation of pro-inflammatory cytokines such as IL-1 $\beta$, IL-2, IL-4, IL-6, IL-13 and TNF- $\alpha$, as well as chemokines such as IL8, Gro $\alpha$ and interferon $\gamma$ (IFN $\gamma$ ) (Brzoska et al, 2008). Furthermore, chemotaxis induced by IL8 in the cells of human neutrophils and monocytes has been suppressed under the influence of $\alpha$-MSH (Manna et al, 2006), which indicates that the function of these types of phagocytic cells during the inflammatory response is blocked by the peptide via multiple effector pathways. Contrary to the inhibitory effects of $\alpha-\mathrm{MSH}$ on the production and activity of proinflammatory mediators, it has been found that $\alpha$-MSH induces IL-10, a cytokine with a potent anti-inflammatory activity. Specifically, in monocytes of human peripheral blood and cultivated human monocytes, $\alpha-\mathrm{MSH}$ increases the production and expression of IL-10 (Bhardway et al, 1996). Since IL-10 reduces the production of pro-inflammatory cytokines in macrophages, its upregulation could result in anti-inflammatory influences.

Studies on different cell types of human skin, including pigment cells, fibroblastic cells and dermal microvascular endothelial cells, as well as rat mast cells, showed that $\alpha-\mathrm{MSH}$ is able to suppress the expression of several intracellular adhesion molecules (interstitial adhesion molecule-1 - ICAM-1 and P-selectin) induced by proinflammatory stimuli such as IFN- $\gamma$, LPS and TNF- $\alpha$ (Böhm et al, 2005; Hill et al, 2006; Sarkar et al, 2003). Finally, the inhibition of adhesion and transmigration of inflammatory cells may contribute to the anti- 
inflammatory potential of $\alpha-\mathrm{MSH}$ (Böhm et al, 2005; Scholzen et al, 2003). Moreover, it was found that $\alpha-\mathrm{MSH}$ inhibits the maturation of dendritic cells and downregulates the expression of co-stimulatory molecules on antigen-presenting dendritic cells, such as CD86, CD40 and CD54 (Luger, 2003; Capsoni et al, 2007).

One of the mechanisms that could explain the anti-inflammatory action of $\alpha-\mathrm{MSH}$ is the suppression of pro-inflammatory non-cytokine mediators under the influence of this peptide. The inhibitory effect of $\alpha-\mathrm{MSH}$ on the synthesis of prostaglandin has long been known. This peptide suppressed the synthesis of PGE in the fibroblast of foetal human lung stimulated with IL-1 (Cannon et al, 1986). The effect of $\alpha-\mathrm{MSH}$ on the synthesis of PGE is cell specific. Confirmation of this is the fact that under the influence of $\alpha-\mathrm{MSH}$, TNF $\alpha$-induced production of PGE2 in FM55 melanoma cells was blocked, but not in HaCaT keratinocytes (Nicolaou et al, 2004).

The induction of the inducible form of the enzyme nitric oxide synthase (iNOS) and the release of gaseous vasodilator nitric oxide (NO) after the stimulation of cells with various pro-inflammatory stressors, i.e. LPS, $\gamma$-IFN and $\beta$-amiloid, can also be suppressed under the influence of $\alpha$-MSH (Tsatmali et al, 2000; Gupta et al, 2000; Caruso et al, 2007; Jung et al, 2007). The increased expression of NOS, and nitration of cellular proteins in the blood and synovial fluid of a patient with rheumatoid arthritis has been registered. Immunomodulatory effects of $\alpha$-MSH realized through $\mathrm{NO}$ may be more important in rodent than in human cells, since human monocytes are known to contain only marginal amounts of this gaseous mediator.

Recent studies have shown that $\alpha$-MSH inhibits the production of superoxide radicals in neutrophils of rats treated with LPS or forbolester (Oktar et al, 2004). Similarly, $\alpha-\mathrm{MSH}$ reduced the amount of oxidative burst in HL-60 cells, a cell line of human monocytes (Manna et al, 2006). Although there is no evidence to suggest that $\alpha-\mathrm{MSH}$ itself is a real radical quencher, these findings are in accordance with other reports that indicate an effect of this peptide on cellular redox balance and the process of apoptosis as well.

Regarding the release of histamine by mast cells, various effects of $\alpha$-MSH have been described which are likely related to species-specific differences, the type of mast cells and experimental conditions. In mast cells obtained from rat bone marrow, $\alpha-\mathrm{MSH}$ inhibited the antigen-induced histamine release together with the suppression of other pro-inflammatory cytokines (Adachi et al, 1999).

There are only a few studies that have researched the effect of $\alpha-\mathrm{MSH}$ on the function of lymphocytes, probably due to the fact that the total expression of melanocortin receptors in several lymphocyte lines is low or undetectable (Andersen et al, 2005). It is known that $\alpha$ MSH induces subpopulation of regulatory T lymphocytes. Regulatory T cells induced with $\alpha-\mathrm{MSH}$ are characterized by the expression of CD25, CD4 and CTLA4 and production of increased levels of TGF- $\beta 2$ (Namba et al, 2002). In the human system, $\alpha-\mathrm{MSH}$ also expresses modulator effects on T cells. Cooper and associates (2005) found that $\alpha-\mathrm{MSH}$ suppresses the proliferation of human $\mathrm{T}$ lymphocytes stimulated by streptokinase/streptodornase. This inhibitory effect of $\alpha-\mathrm{MSH}$ was independent of the genotype MC-1R, which is highly polymorphous with more than 35 genetic variations.

Numerous effects of $\alpha-\mathrm{MSH}$ on the production of inflammation mediators were a mystery to researchers until it was found that this peptide inhibits the activation of the nuclear factor kappa B (NF-кB) (Mandrika et al, 2001; Hassoun et al, 2002). This essential nuclear factor induces the transcription of many molecules involved in the inflammatory process, and 
therefore its inhibition results in the alteration of mediators' production and cell functions. $\mathrm{NF}-\kappa \mathrm{B}$ participates in the regulation of hundreds of genes, including those for cytokines, chemokines, factors for haematopoietic system growth, antiapoptotic factors and the inducible synthesis of nitric oxide (iNOS). Therefore, the discovery that $\alpha$-MSH inhibits activation of NF- $\mathrm{KB}$ provides an explanation for numerous effects of this peptide on the production of mediators.

Anti-inflammatory effects of $\alpha-\mathrm{MSH}$ in vitro have also been identified in vivo in various animal models. These have confirmed a number of effects of melanocortin on the production of mediators of inflammation. The anti-inflammatory activity of $\alpha-\mathrm{MSH}$ in animal models of arthritis is of special interest. Repeated intraperitoneal application of the peptide twice daily resulted in a significant reduction of clinical and histological signs of adjuvant-induced experimental arthritis as compared to control animals. The efficiency of $\alpha-\mathrm{MSH}$ was similar to that of prednisolone, but $\alpha$-MSH did not cause significant weight loss (Ceriani et al, 1994). Some data indicate that the melanocortin receptor MC-3R may be a relevant target for the treatment of arthritis.

During the early phase of inflammation (associated with tissue destruction and activation of nociceptors) mediators of inflammation, including cytokines, chemokines, bradykinin, prostaglandins act as mediators of hyperalgesia. At the same time, the expression of peripheral opioid receptors on sensory nerve endings increases during inflammation (Rittner et al, 2003), which leads to the release of pain mediators, such as opioid peptides, somatostatin, endocannabinoids and certain cytokines. Endogenous opioid peptides, leucine and met-enkephalin act presynaptically when they inhibit the release of neurotransmitters, and postsynpatically when they suppress the activity of the postsynaptic neurone, and block the transmission of ascending pain signals (Rang, 2005).

In addition to the central nervous system, met-enkephalin influences the function of the immune system (Vujić-Redžić, 2000). It is released from polymorph nuclear cells during inflammation and periods of stress (Rittner et al, 2006). In inflammation, there is a migration of leukocytes that contain opioid peptides, and also the upregulation of opioid receptors of afferent fibres. This is supported by the fact that IL-1 $\beta$ is a specific inductor of expression of kappa opioid receptors (Puehler et al, 2006). Interleukin-1, together with TNF-a, is the main proinflammatory cytokine released from macrophages and many other cells, which initiates the release of other cytokines (Rajora et al, 1997).

In in vitro studies, it was found that $\mathrm{T}$ lymphocytes have opioid receptors on their surface (Wybran et al, 1985), and according to Plotnikoff and associates (1991), the effects of enkephalin are precisely related to the immune response mediated by $\mathrm{T}$ cells. In addition, the corticotropin-releasing hormone, similarly to the pituitary gland, appears dosedependent locally, through delta opioid receptors, and leads to the release of opioid peptides from leukocytes and the induction of endogenous analgesia (Menzebach et al, 2003; Cabot et al, 2001).

Met-enkephalin manifests central, bimodal and dose dependent immunomodulatory effects. A bi-phasic effect was registered in in vivo studies on rats. High doses have suppressed, while low doses potentiated a humoral immune response (Janković and Marić, 1994). The studies in vivo of the immunomodulatory effect of met-enkephaline on rats showed a suppressive action of high doses of met-enkaphalin on inflammatory reactions, such as the systemic anaphylactic shock (Janković and Marić, 1987), Arthus phenomenon and postponed skin reactions to protein antigens (Marić and Janković, 1987), the rejection of 
allograph (Janković, 1991), arthritis (Janković, 1991) and the experimentally induced allergic encephalomyelitis (Veljić et al, 1991).

In studies conducted at the Charite University in Berlin on the effect of intraarticular application of opioids in comparison to the intraarticular application of glucocorticoids in patients with the chronic inflammatory arthritis accompanied by pain and functional impairment, according to the established hypothesis, local application of opioids led to a significant reduction of pain and inflammation, which can be explained by the activation of peripheral opioid receptors (that have been identified on peripheral sensory nerve endings), and subsequent decreases in neural excitability, transmission of nociceptive impulses, and reduced release of proinflammatory neurotransmitters (Stein et al, 2001; Mousa et al, 2001). In summary, preclinical studies indicate that the activation of melanocortin receptors could be a new strategy to control inflammation (Catania et al, 2004). Similarly to any new therapeutic approaches, this strategy may have both advantages and disadvantages in comparison to the currently available medications. The main advantage of melanocortin in the treatment of inflammation is that its anti-inflammatory activity is not restricted to a specific mediator or a chemical process. In fact, as a consequence of reduced activation of the nuclear factor NF- $\mathrm{kB}$, the collective reduction of all important molecules involved in the inflammatory process is evident.

Another positive aspect is the fact that the treatment with melanocortin peptides never reverses the inflammatory response, but modulates it. It is well known that the inflammatory response is a crucial reaction of the host that contributes to the elimination of pathogens and harmful molecules. Cytokines, which are a major component of the inflammatory process, also have a significant function in regulating the recovery of tissues, haematopoiesis and immune responses. Any agent that completely inhibits their production or action would have a detrimental impact on the host defence mechanism. Melanocortin peptides modulate the increased production of cytokines during infection or inflammation, but do not prevent their release. Besides, they do not affect the production of mediators of inflammation when being on complete rest. So, for example, alpha-1-13 corticotrophin modulates the febrile response caused by pyrogens, while on the other side, it does not cause any changes to the non-febrile temperature of the body.

The main advantage of the melanocortin in relation to the currently used anti-inflammatory drugs, particularly corticosteroids, is that neuropeptides do not reduce the microbicidal activity of neutrophils, but instead increase it. This feature could be very important in the treatment of inflammation in immunecompromised persons.

The lack of selectivity could be a potential problem when it comes to the use of natural melanocortin peptides. Today, it is clear that the melanocortins affect many body functions, including the regulation of food consumption, sexual behaviour and pigmentation. Systemic injection of non-selective peptide could, therefore, cause adverse effects by stimulating all subtypes of receptors. However, the design and synthesis of new melanocortin analogues with a selective affinity for specific receptors could greatly facilitate the achievement of target effects. Knowledge of amino acid substitution that reduces binding to all receptors can also help prevent unwanted receptor activation. (Catania et al, 2004). Another potential problem lies in the rapid splitting, or degradation of peptide molecules in the circulation and other body fluids, and natural melanocortins are no exception.

The relatively short half-life could be a problem if it is necessary to maintain the concentration in the blood. On the other hand, the fact that the peptides are not accumulated 
in the body reduces the likelihood of toxicity and tolerance, and allows for better control of the pharmacological effects (Catania et al, 2004).

\section{Preclinical toxicological studies}

Enkorten toxicity testing was conducted according to the Instructions and Rules of Good Laboratory Practice (GLP) and Harmonized Tripartite Guideline issued in 1998.

Objectives of preclinical toxicological studies were to determine the degree of toxicity of the investigated substance; to identify the target organs of toxicity and to determine the reversibility of the toxic effects; to detect the toxic effects that may help in the identification of the parameters for subsequent clinical trials and to determine the maximum tolerated dose.

Preclinical toxicological studies were carried out in rats and rabbits. The experimental animals were Wistar albino rats bred in the breeding quarters in Harlan, Italy, and the rabbit strain was HY plus giant PS 19 gene, from France. Environmental conditions for animals in the vivarium were maintained constant with daily temperature and humidity monitoring. Semisynthetic food for laboratory animals ad libitum and the tap water that meets the Sarajevo city water-supply criteria for drinking water were used during study. Animals were randomly divided in groups according to dose levels. Three dose levels were determined using the method of multiplication of the anticipated maximum human therapeutic dose of $10 \mathrm{mg}$ of met-enkephalin (substance a) and $2 \mathrm{mg}$ of alpha-MSH (substance b): the dose equivalent to the anticipated human therapeutic dose $(0.071 \mathrm{mg} / \mathrm{kg}$ $\mathbf{a}+0.014 \mathrm{mg} / \mathrm{kg} \mathrm{b}) ; 5$ times higher dose $(0.355 \mathrm{mg} / \mathrm{kg} \mathbf{a}+0.07 \mathrm{mg} / \mathrm{kg} \mathbf{b}) ; 10$ times higher dose $(0.71 \mathrm{mg} / \mathrm{kg} \mathbf{a}+0.14 \mathrm{mg} / \mathrm{kg} \mathbf{b})$. Enkorten was applied as a constant volume dose of $0.0005 \mathrm{ml} / \mathrm{g}$ according to the following dosage regime: during the first month - three times a week; during the second month - twice a week, and during the third month - once a week. The control group was treated by $0.9 \%$ of physiological $\mathrm{NaCl}$ solution.

Treatment was followed by a 10-day observation period. The appearance of toxic signs was monitored on a daily basis. Weighing of individual animals was performed before dosing, once a week, and before the animals were sacrificed. Daily food and water consumption per cage, as well as the stool mass were recorded on a weekly basis.

In subchronic and chronic studies, haematological and biochemical analyses were performed of the fasting blood samples taken from 12 animals from each of the experimental groups and from 24 animals from the control group, before the animals were sacrificed. The following haematological analyses were performed: hematocrit, haemoglobin concentration, red blood cell count, red blood cell morphology, total and differential white blood cell count, platelets. The following biochemical analyses were performed: Calcium $\left(\mathrm{Ca}^{+2}\right)$, Potassium $\left(\mathrm{K}^{+}\right)$, Sodium $\left(\mathrm{Na}^{+}\right)$, Chloride $(\mathrm{Cl}-)$, Phosphorus $\left(\mathrm{PO}_{2}{ }^{4-}\right)$, glucose, Aspartal aspartate aminotransferase (AST), Alanine aminotransferase (ALT), alkaline phosphatase $(\mathrm{AP})$, Gamma-glutamyl transpeptidase (GGT), blood urea nitrogen (BUN), total proteins, albumin, globulin, total bilirubin, creatinine, lipids, and cholinesterase.

Necropsy was performed only on the sacrificed animals (no lethality observed). Upon completion of the experiment, animals were sacrificed and both external and internal examinations of the sacrificed animals were performed. The following organs: brain, heart, lungs, liver, spleen, thymus, kidneys and adrenal glands, as well as samples of other macroscopically changed tissues were subjected to histopathological analysis. 
Collected data were statistically analyzed using the Microsoft ${ }^{\circledR}$ Excel 2002 and SigmaStat programs for statistical analysis.

\subsection{Acute toxicity study}

The acute toxicity study was performed as the initial step of the prospective drug toxicological evaluation. Acute toxicity provides the important safety parameters for the prospective human overdose scenario and its expected clinical presentation. Traditionally, international authorities and governmental agencies had adopted the mean lethal dose as the sole measurement of acute toxicity. Testing of the rationally high doses, without detected lethality, is also acceptable and complies with the Limit Test concept (ICH, 2009; EMA, 2010).

Acute toxicity was assessed on Wistar albino rats. The study was performed as the single dose testing following intravenous (i.v.), subcutaneous (s.c.) and intraperitoneal (i.p.) application, in accordance with the Limit Test methodology. The administered multiplications were: via i.v. route 50, 100 and 200 times; via s.c. route 100, 250 and 500 times; and via i.p. route 100, 250, 500 times plus 1000 times in and additional group of males. Neither lethality, nor significant macroscopic and microscopic changes were observed at the necropsy following planned sacrificing. The necropsy and histopathological evaluation revealed no significant changes. No statistically significant differences in post-mortem organ weights were noted.

The most prominent clinical signs were noted on day 1 of the observation period. Following all three application routes, slightly reduced motor activity and the horizontal positioning of the tail was observed in all animals treated with the highest i.v. dose. There was a slight ptosis (eyelids down $1 / 4$ ) in a few animals in all i.v. treatment groups. Slight cyanosis and general vasoconstriction was noted in one male treated with the highest i.v. dose, and one male treated with the medium i.v. dose. Slightly slower motor activity of all treated and control animals was observed following the s.c. application. Also, slight muscular hypotonia was noted on day 3 in three males treated with the highest dose and one male treated with the lowest dose. Irregular breathing, decrease in motor activity, somnolence, ataxia, catalepsy and muscular hypotonia were observed in all males from the additional group administered i.p. with 1000 dose multiplication. A proportion of the effects noted could be attributed to the application of the large amount of fluid, since the constant volume was not respected for this group. Afterwards, the frequency and character of breathing were observed once a week and were found to remain within the physiological limits.

Intensive phonation during the manipulation with animals was registered for i.v. dosed groups. The frequency of intensive phonation intensified between days 9 and 14 of the observation period, which was not noted in control animals. Statistically significant difference was detected for increased phonation in all treatment groups of males, IVF3 and IVF2, compared to controls ( $\mathrm{p} \leq$ 0.000001). Following the s.c. application, each phonation was registered, and there was no prominent difference in phonation in males, while a statistically significant difference in phonation was noted for group SCF3 $(p=0.000001)$, compared to the control.

The tested combination induced no lethality and demonstrated a low level of toxicity in high doses. The fact that neither organ or tissue damage, nor organ mass ratio differences in control and experimental groups were detected indicates that the application of the tested 
combination to the rats did not result in a permanent adverse toxicological effect on the examined organs. Reversible signs of toxicity disappeared with substance elimination and usually were not followed by a permanent tissue damage.

High doses of met-enkephalins produce effects on $\mathrm{OP}_{3}(\mu)$ receptors in the range of sedation, mood changes, miosis, respiratory depression and gastrointestinal disturbances (Plotnikoff et al., 1997; Brunton and Parker, 2008). The evidence of ptosis, motor activity changes, horizontal positioning of the tail or increased phonation could suggest opioid pathway engagement. Increased intensity of phonation was clearly noted for all i.v. dosed treatment groups, but not at all in control animals (Rakanović-Todić et al, 2011).

\subsection{Subacute toxicity study}

The subacute toxicity study with the subcutaneous (s.c.) administration of Enkorten was conducted with three experimental groups, each of 10 Wistar albino rats (both males and females) and the control group of 20 Wistar albino rats (both males and females) during four weeks. Neither lethal outcomes nor toxic signs were observed during the study. The absence of pronounced toxicity of the substances was confirmed by the body weight gain in both experimental and control groups of animals during the study period. The ability of gaining or maintaining the body weight is considered to be a non-specific indicator of the health status of the animal (Gad and Chengelis, 1998), especially in toxicity studies with multiple applications. Furthermore, the average food and water consumption as well as the percentage ratio of stool mass were balanced between male and female groups. Neither external nor internal examination of animals sacrificed at the end of the study revealed any macroscopic pathological changes. Histopathological analysis revealed no microscopic pathological changes in tissue samples of liver, kidneys, lungs, heart, brain, spleen and thymus. All examined tissues showed a normal structure. No statistically significant differences in post-mortem organ weights were noted between male and female groups. The results of subacute toxicity study indicated that the tested combination of substances was not toxic when administered s.c. and repeatedly during four weeks (Todić et al, 2007).

\subsection{Subchronic toxicity study}

The subchronic toxicity study with intramuscular administration of Enkorten was conducted with three experimental groups, each of 10 Wistar albino rats (both males and females) and the control group of 15 Wistar albino rats (both males and females) during three month.

As a part of this study, the electrocardiogram (ECG) was recorded in 6 animals from each of the experimental groups ( 3 males +3 females) and from the control group ( 3 males +3 females), which in total amounts to 24 animals. The ECG was recorded on the day before the study commenced, as well as during the third, fifth, seventh, ninth and the eleventh week of the study and on the day before the planned sacrificing of animals. The electrocardiograph Schiller Resting ECG, connected to a personal computer was used for ECG registration. The computer program SEMA - 200 Vet (a program for ECG analysis in veterinary medicine) was used for the analysis of the registered curves. This program calculated the average values of the heart rate (FSR bits/min) and the duration of the RR interval (ms), P wave (ms), PQ interval (ms), QRS complex (ms) and QT interval (ms). 
In the subchronic toxicity study, not a single lethal outcome was registered. No statistically significant differences between experimental and control groups in body weight of animals, in food and water consumption were documented. No statistically significant differences between experimental and control groups in the sensitivity to pain, frequency of breathing, were detected, nor differences in post-mortem organ weights during macroscopic examination and histopathological analysis of the tissue samples. No statistically significant differences were found between experimental and control groups in the average duration of ECG parameters and biochemical parameters in males. The results of the investigation of the Enkorten influence on the biochemical parameters in females showed the following statistically significant differences: in the values of calcium $(p=0.046)$ between the third and the first group (FG3 vs. FG1); in the values of sodium $(p=0.044)$ although no statistically significant differences were documented in the sodium values between the individual experimental groups and the control group; in the values of urea $(\mathrm{p}=0.049)$ although no statistically significant differences in the urea values between the individual experimental groups and the control group were documented; in the values of ASAT $(p=0.020)$ between the first and the control group; in the values of cholinesterase $(p=0.036)$ between the first and the control group (FG1 vs. FGK). It may be concluded that Enkorten probably affected the values of ASAT and cholinesterase in females, whereas the differences in the values of calcium, sodium and urea were probably due to chance. The results of the haematological parameters showed no statistically significant differences. It can be concluded that the tested substance had no impact on haematological parameters. Test results of the toxic effect investigation suggested that the maximum tolerated dose for male and female rats approximately corresponds to the dose 10 times higher than the anticipated human therapeutic dose. Based on the estimates obtained, we can conclude that in the study conducted in male and female Wistar albino rats, the investigated product showed no subchronic toxicity when the multiple i.m. application of animal doses equivalent to the either anticipated human therapeutic dose, or 5 or 10 times higher dose was performed.

During the implementation of the subchronic Enkorten toxicity study in rabbits, individual cases of mortality, that cannot be linked with the activity of the test substance, have been documented in all experimental groups.

\subsection{Chronic toxicity study}

Based upon results of the chronic toxicity study performed on rats after the subcutaneous administration of Enkorten (three experimental groups, each of 40 Wistar albino rats and a control group) during six months, it was concluded that test substance did not show any toxic effects. In the course of the chronic toxicity study, not one lethal outcome was registered. In the course of pain sensitivity testing, the tested substance did not demonstrate a significant analgesic effect. Moreover, it was found that the tested substance increases the irritability of animals in the sense that it increases the frequency of phonation. The histopathology laboratory reports recorded no changes with respect to the mass of single organs or with respect to the macroscopic and microscopic structure of organs and tissues of experimental animals. The difference is noted in the mass of the left adrenal in the control and the first group in relation to administering the combination to male rats. Impact of tested substances on biochemical parameters in males showed statistically significant difference between the first and the control groups, as well as between the second and the 
control group in the values of phosphorous, alkaline phosphates, and urea. The difference in triglycerides between the first and the control group, the AST values between the second and third group and the first and the third group, the ALT values between the second and the control group were also noticed. The sifnificant difference in the values of these parameters for males may be coincidental, because the difference between the groups treated by the highest dose level and the control group was not registered. In females a statistically significant difference in calcium and potassium was registered between the treated and the control groups. The values of phosphorus and alkaline phosphatase significantly differed between the first and the control group, and urea value between the first and the control group. Triglyceride statisticaly levels of all three treated groups significantly differed from the control group values. Also, there was a significantly difference in the values of ALT between the second and the control group. These data suggest that tested substance affects the value of calcium, potassium and triglycerides in females. The value difference of other parameters can be random, because the difference between the groups treated with the highest dose level and the control group was not registered. The data on the volume and biochemical parameters of urine showed statistically non significant difference between control and other groups of animals. Statistically significant difference between the control and first group of animals was found only in glucose during the second measurement. Registered difference is probably a consequence of stress.

Statistical analyses of the results obtained after biochemical analyses were not statistically significant (including both male and female groups) for the following parameters: $\mathrm{Ca}^{+2}, \mathrm{~K}^{+}$, $\mathrm{Na}^{+}, \mathrm{Cl}$, glucose, total proteins, albumins, globulins, total bilirubin, creatinine, cholesterol, cholinesterase, AST, GGT.

The tested substance has no effect on the parameters of erythrocytes, leukocytes, granulocytes, thrombocytes and lymphocytes. However, the tested substance has effects on the value of monocytes when compared to the control group, and, as far as males are concerned, also in the values of lymphocytes. The tested substance did not have effects on the volume and biochemical parameters of urea, except for the glucose report. The noted difference is, probably, the result of stress (Bečić et al, 2007).

\subsection{A pilot study of the reproductive toxicity in rats}

Testing was conducted at the Institute following the NTP, 2002 (NTP - National Toxicology Program - Good Science and Good Decisions - NIEHS, USA, 2002), in five months old, adult male and female laboratory Wistar albino rats (the Institute's own breeding colony).

In the first phase, Enkorten in a doubled human therapeutic dose (2HD; a-MSH 0.028 $\mathrm{mg} / \mathrm{kg}+$ met-enkephalin $0.143 \mathrm{mg} / \mathrm{kg}$ ) was administered once intraperitoneally (i.p.). Afterwards, animals were administered a bilateral intranasal (i.n.) dose of Enkorten eight times higher than the human therapeutic dose (8HD) per day, within two consecutive days. Administration of the substance in the above doses was carried out using the methods of crossing and gender matching. In the second phase, the same dosing protocol but with the i.n. dose increased to twenty times human therapeutic dose (20HD) was administered to the $F_{1}$ generation of male and female rats, after they reached sexual maturity. By applying the same protocol, the control group received a physiological solution. During the first and the second phase, the typical parameters of the reproductive capacity of the animals from the $\mathrm{F}_{0}$ 
and $F_{1}$ generations (gestation, litter and lactation) as well as the litter of the $F_{1}$ and $F_{2}$ generations (number of offspring per litter, size, weight, growth, development and advancement until the age of 8 weeks) were followed. At the end of the study, post mortem analysis was performed on the tissue and reproductive organs of young male and female rats from the $\mathrm{F}_{2}$ generation.

Comparing to controls, Enkorten did not cause any changes in the first phase of testing. In the second phase of the study, no gestation appeared in the experimental group from the $F_{1}$ generation, whereas in the remaining four groups the reproduction process was completely in accordance with the control. The number of offspring per litter ranged from 8 to 12. The size and weight of youth as well as gender contribution were fully in compliance with the control group. The development, growth, advancement of youth and lactation were progressing normally. Development was monitored until the age of 8 weeks of life, after which histopathological analysis of tissues and reproductive organs was performed. Post mortem analyses did not reveal significant changes in any of the young animals. No signs of teratogenicity were documented in the two generations of young rats.

Based on the observed results, it can be concluded that Enkorten did not significantly affect the process of reproduction in rats. Enkorten did not cause any teratogenic changes. Histopathological reports were completely normal.

\subsection{Investigation of the effect on skin}

The investigation of the effect of Enkorten on skin was conducted using the mouse ear model (according to: Hypersensitivity Test Methods: NTP-National Toxicology Program Good Science and Good Decisions - NIEHS, USA, 2002).

Adult BALB/c male and female mice, divided into groups of 6 animals (the Institute's own breeding colony) were receiving Enkorten in 2HD (a-MSH $0.028 \mathrm{mg} / \mathrm{kg}+$ met-enkephalin $0.143 \mathrm{mg} / \mathrm{kg}$ ) per day, by i.p. route, during 4 days. As an irritant, croton oil (3\%, in acetone) was applied topically, in a volume of $25 \mu \mathrm{L}$, once, at the fifth day of the first Enkorten application. By applying the dose of Enkorten in such conditions, the irritation/inflammation process on the mouse skin caused by croton oil was inhibited by $35 \%$ compared to the control group that received the physiological solution. Enkorten action was slightly more pronounced in males during the first 24 hours.

The doubled human therapeutic dose of Enkorten, applied topically to skin in a volume of $25 \mu \mathrm{L}, 6$ hours prior to the irritant application (3\% croton oil in acetone, in the volume of 25 $\mu \mathrm{L}$, topically), led to the inhibition of the irritation/inflammation processes by $57 \%$ to $60 \%$, compared to both male and female control mice.

It can be concluded that Enkorten administered preventively, in a dose equivalent to the doubled human therapeutic dose, by i.p. route, during 4 days, reduced the irritation/inflammation processes for about 35\%. Compared to the control, this drug, applied once, topically, reduced irritation/inflammation processes caused on the mouse skin by $60 \%$.

\section{Pharmacokinetic study}

The aim of this study was to assign the range of values of a-MSH and met-enkephalin plasma concentrations before and after the Enkorten application and to determine pharmacokinetic parameters of the test preparation $\left(C_{\max }, T_{\max }, A U C, T_{1 / 2}\right) . C_{\max }$ (Maximum 
Plasma Concentration) is the highest concentration of drug in the blood that is measured after a dose; $\mathrm{T}_{\max }$ (Time to Reach $\mathrm{C}_{\max }$ ) is the time at which the highest plasma drug concentration occurs $\mathrm{C}_{\max }$; AUC (Area Under the Curve) is the measure of total plasma exposure of drug over a given time period; $\mathrm{T}_{1 / 2}$ (Half-life) is the time required for a given drug concentration to decrease by $50 \%$.

The study was carried out on a group of 14 healthy volunteers, ages from 18 to 30, males, of body weight and height within the standard values.

All volunteers received subcutaneously one dose of Enkorten preparation in the presumed therapeutic dose for human application. No serious side-effects were observed during the study. The available kit is not specific for the determination of a-MSH of the test preparation; thus, the cross-reactivity of physiologically present a-MSH and a-MSH component of the preparation was determined. Significant interindividual differences of aMSH plasma concentration were found. Mean values were $21.31-47.56 \mathrm{pg} / \mathrm{ml}$. Mean plasma concentration of endogenous met-enkephalin was $50.40 \mathrm{pg} / \mathrm{ml}$. Maximum plasma concentration after Enkorten application, measured 5 minutes after the application, was $1551.86 \mathrm{pg} / \mathrm{ml}$. The plasma half-life was 15 minutes. The concentration/time curve of metenkephalin implies first-order kinetics (Kusturica et al, 2009).

\section{Conclusion}

Enkorten is an immunomodulatory preparation containing two components, a-melanocyte stimulating hormone (a-MSH) and methionine-enkefalin (met-enkephalin). a-MSH and met-enkephalin are endogenous substances of the neuropeptide group. They participate in the homeostatic processes, maintaining the biochemical link between the brain, neuroendocrine system and the immune system. The mechanism of action of both peptides directly reclines on both mechanisms of immune response development. The effect also includes analgesia, antipyretic and anti-inflammatory activities.

Pharmacodynamics of the combination shown in the studies imply great therapeutic possibilities. The presumed indication range of Enkorten encompasses diseases with inflammatory processes as the primary pathophysiological aspect (asthma, inflammatory bowel disease, rheumatoid arthritis, multiple sclerosis).

Preclinical findings indicate that the tested combination was nontoxic and well tolerated in doses applied by i.v., s.c., i.m., and i.p. routes, and therefore have the potential for safe future use as a medicine.

\section{References}

Adachi, S., Nakano, T., Vliagoftis, H., Metcalfe, D.D. (1999). Receptor-mediated modulation of murine mast cell function by $\alpha$-melanocyte stimulating hormone. J Immunol 163: 3363-3368.

Andersen, G.N., Hagglund, M., Nagaeva, O., Frangsmyr, L., Petrovska, R., MinchevaNilsson, L., Wikberg, J.E. (2005). Quantitative measurement of the levels of melanocortin receptor subtype 1, 2, 3 and 5 and pro-opiomelanocortin peptide gene expression in subsets of human peripheral blood leucocytes. Scand J Immunol 61: 279-284. 
Bečić, F., Mulabegović, N., Kapić, E., Rakanović-Todić, M., Kusturica, J., Ašćerić, M., LogaZec S. (2007). Evaluation of toxicity of combination met-encephaline and alphamelanocyte-stimulating hormone with the aim to calculate clinical studies. $8^{\text {th }}$ Congress of the European Association for Clinical Pharmacology and Therapeutics. Amsterdam, Medimond S.r.l: 221-226.

Bhardwaj, R.S., Becher, E., Mahnke, K., Hartmeyer, M., Schwarz, T., Scholzen, T. et al. (1997). Evidence for the differential expression of the functional alpha melanocyte stimulating hormone receptor MC-1 on human monocytes. J Immunol 158: 33783384 .

Böhm, M., Eickelmann, M., Li, Z., Schneider, S.W., Oji, V., Diederichs, S., Barsh, G.S., Vogt, A., Stieler, K., Blume-Peytavi, U., Luger, T.A. (2005). Detection of functionally active melanocortin receptors and evidence for an immunoregulatory activity of $\alpha$ melanocyte-stimulating hormone in human dermal papilla cells. Endocrinology 146: 4635-4646.

Brunton, L.L., Parker, L.K. (eds.) Goodman and Gilman's Manual of Pharmacology and Therapeutics, $1^{\text {st }}$ edition. McGraw-Hill Companies, 2008; p 349-382, 1023-1036.

Brzoska, T., Luger, T.A., Maaser, C., Abels, C., Böhm, M. (2008). $\alpha$-Melanocyte-Stimulating Hormone and Related Tripeptides: Biochemistry, Anti-inflammatory and Protective Effects in Vitro and in Vivo, and Future Perspectives for the Treatment of ImmuneMediated Inflammatory Diseases. Endocrine Reviews 29 (5): 581-602.

Cabot, P.J., Carter, L., Schäfer, M., Stein, C. (2001). Methionine-enkephalin-and Dynorphin A-release from immune cells and control of inflammatory pain. Pain 93(3): 207-212.

Cannon, J.G., Tatro, J.B., Reichlin, S., Dinarello, C.A. (1986). $\alpha$-Melanocyte stimulating hormone inhibits immunostimulatory and inflammatory actions of interleukin $1 . J$ Immunol 137: 2232-2236

Capsoni, F., Ongari, A., Colombo, G., Turcatti, F., Catania, A. (2007). The synthetic melanocortin (CKPV)(2) exerts broad anti-inflammatory effects in human neutrophils. Peptides 28(10): 2016-2022.

Caruso, C., Durand, D., Schiöth, H.B., Rey, R., Seilicovich, A., Lasaga, M. Activation of melanocortin 4 receptors reduces the inflammatory response and prevents apoptosis induced by lipopolysaccharide and interferon- $\gamma$ in astrocytes. Endocrinology 148: 4918-4926.

Catania, A., Airaghi, L., Colombo, G. and Lipton, M.J. (2000). $\alpha$ - Melanocyte-stimulating hormone in Normal Human Physioligy and Disease States. TEM 11 (8): 304-308.

Catania, A., Cutuli, M., Garofalo, L., Carlin, A., Airaghi, L., Barcellini, W. and Lipton, J.M. (2000a). The neuropeptide alpha- MSH in host defence. Amm NY Acad Sci 917: 227231.

Catania, A., Delgado, R., Airaghi, L., Cutuli, M., Garofalo, L., Carlin, A., Demitri, M.T., Lipton, J.M. (1999). Alfa-MSH in Systemic Inflammation: Central and Peripheral Actions. Annals of the New York Academy of Sciences 885:183-187.

Catania, A., Gatti, S., Colombo, G., Lipton, J.M. (2004). Targeting melanocortin receptors as a novel strategy to control inflammation. Pharmacol Rev 56: 1-29. 
Ceriani, G., Diaz, J., Murphree, S., Catania, A., Lipton, J.M. (1994). The neuropeptide alphamelanocyte-stimulating hormone inhibits experimental arthritis in rats. Neuroimmunomodulation 1: 28-32

Cooper, A., Robinson, S.J., Pickard, C., Jackson, C.L., Friedmann, P.S., Healy, E. (2005). $\alpha-$ Melanocyte-stimulating hormone suppresses antigen-induced lymphocyte proliferation in humans independently of melanocortin 1 receptor gene status. $J$ Immunol 175: 4806-4813.

EMA: European Medicines Agency Questions and Answers on the withdrawal of the Note for guidance on single dose toxicity. Committee for Medicinal Products for Human Use. 2010: http:/ / www.ema.europa.eu (accessed November 2, 2010).

Gad, C.S. and Chengelis P.C. Acute Toxicology Testing. Second edition. Academic Press, USA, 1998.

Getting, S.J. (2006). Targeting melanocortin receptors as potential novel therapeutics. Pharmacol Ther 111 (1): 1-15.

Gupta, A.K., Diaz, R.A., Higham, S., Kone, B.C. (2000). $\alpha-\mathrm{MSH}$ inhibits induction of $\mathrm{C} / \mathrm{EBP} \beta$-DNA binding activity and NOS2 gene transcription in macrophages. Kidney Int 57: 2239-2248.

Hassoun, H.T., Zou, L., Moore, F.A., Kozar, R.A., Weisbrodt, N.W., Kone, B.C. (2002). Alpha-melanocyte-stimulating hormone protects against mesenteric ischemiareperfusion injury. Am J Physiol Gastrointest Liver Physiol 282: G1059-G1068.

Hill, R.P., MacNeil, S., Haycock, J.W. (2006). Melanocyte stimulating hormone peptides inhibit TNF-a signaling in human dermal fibroblast cells. Peptides 27: 421-430.

ICH: International Conference on Harmonisation. Guidance on Nonclinical Safety Studies for the Conduct of the Human Clinical Trials and Marketing Authorization for Pharmaceuticals M3(R2), 2009.

Jankovic, B., Maric, D. Enkephalins as regulators of inflammatory immune reactions. In: Neuropeptides and Immunoregulation. Scharrer et al. Eds. pp: 76-100, SpringerVerlag Berlin Heidelberg, 1994

Jankovic, B.D. (1991). Enkephalins and immune inflammatory reactions. Estrallo da Acta Neurologica 13 (XLVI) N0 5

Jankovic, B.D., Maric, D. (1987). Enkephalins and anaphylactic shock: Modulation and prevention of shock in the rat. Immmunol Lett 15: 153.

Jung, E.J., Han, D.J., Chang, S.H., Lim, D.G., Wee, Y.M., Kim, J.H., Koo, S.K., Choi, M., Kim, S.C. (2007). Protective effect of $\alpha$-melanocyte-stimulating hormone on pancreas islet cell against peripheral blood mononuclear cell-mediated cytotoxicity in vitro. Transplant Proc 39: 1604-1606.

Konjevoda, P., Štambuk, N., Aralica, G., Pokrič, B. (2001). Cytoprotective effects of metencephalin and $\alpha-\mathrm{MSH}$ on ethanol induced gastric lesions in rats. Journal of Physiology 95: 277-281.

Konjevoda, P., Štambuk, N., Vikić-Topić, D., Boban-Blagajić, A., Vikić-Topić, S., Mrljak, V., Pavan, J., Ramadan, P., Bididn, Z. (2000). Protective effects of Met-encephalin on alcohol induced gastric lesions. Croatica Chemica Acta 73 (4): 1111-1121.

Kusturica, J., Mulabegović, N., Kapic, E., Krehić, J., Mandal, S. et Bečić, F. (2009). Pharmacokinetics of Encorten. HealthMed 3 (2):159-165. 
Lipton, J.M., Catania, A., Ichiyama, T. (2000). Marshaling the anti-inflammatory influence of the neuroimmunomodulator $\alpha-\mathrm{MSH}$. News Physiol Sci 15: 192-195.

Lipton, M.J. and Catania, A. (1997). Anti-inflamatory actions of the neuroimunomodulator $\alpha$ - MSH. Immunology today 18 (3): 140-145.

Luger, T.A. et al. (2003). New insights into the functions of alpha-MSH and related peptides in the immune system. Annals of the New York Academy of Sciences 994: 133-140.

Luger, T.A., Brzoska, T. (2007). $\alpha$-MSH related peptides: a new class of anti-inflammatory and immunomodulating drugs. Annals of the Rheumatic Diseases 66 (Suppl 3): iii52iii55.

Mandrika, I., Muceniece, R., Wikberg, J.E. (2001). Effects of melanocortin peptides on lipopolysaccharide/interferon- $\gamma$-induced NF- $\kappa B$ DNA binding and nitric oxide production in macrophage-like RAW 264.7 cells: evidence for dual mechanisms of action. Biochem Pharmacol 61: 613-621.

Manna, S.K., Sarkar, A., Sreenivasan, Y. (2006). $\alpha$-Melanocyte-stimulating hormone downregulates CXC receptors through activation of neutrophil elastase. Eur J Immunol 36: 754-769.

Menzebach, A., Hirsch, J., Hempelmann, G., Welters, D. (2003). Effects of endogenous and synthetic opioid peptides on neutrophil function in vitro. British Journal of Anaesthesia 91(4): 546-550.

Mousa, S.A., Zhang, Q., Sitte, N., Ji, R., Stein, C. (2001). Beta-Endorphin-containing memorycells and mu-opioid receptors undergo transport to peripheral inflamed tissue. $J$ Neuroimmunol 115: 71-78.

Mulabegović, N., Rakanović-Todić, M. (2008). Pharmacodynamic Properties of Combination of Met-enkephalin and Alpha 1-13 Corticotropine. Medicinski Arhiv 62(1):41-4.

Namba, K., Kitaichi, N., Nishida, T., Taylor, A.W. (2002). Induction of regulatory T cells by the immunomodulating cytokines alpha-melanocyte-stimulating hormone and transforming growth factor-beta2. J leukoc Biol 72; 946-952.

Nicolaou, A., Estdale, S.E., Tsatmali, M., Herrero, D.P., Thody, A.J. (2004). Prostaglandin production by melanocytic cells and the effect of $\alpha$-melanocyte stimulating hormone. FEBS Lett 570: 223-226.

Oktar, B.K., Yuksel, M., Alican, I. (2004). The role of cyclooxygenase inhibition in the effect of $\alpha$-melanocyte-stimulating hormone on reactive oxygen species production by rat peritoneal neutrophils. Prostaglandins Leukot Essent Fatty Acids 71: 1-5.

Plotnikoff, N., Faith, R.E., Murgo, A.J., Herberman, R.B., Good, R.A. (1997). Short analytical review: Methionine enkefalin: A new cytokine-human studies. Clinical Immunology and Immunopathology 82(2): 99-101.

Plotnikoff, N.P., Wybran, J. (1991). Methionine enkephalin: activation of NK-K-LAK cells in AIDS patients. Int Conf AIDS. Jun 16-21; 7: 216 (abstract no. W.B.2139).

Puehler, W., Rittner, H.L., Mousa, S.A., Brack, A., Krause, H., Stein, C. (2006). Interleukin-1 beta contributes to the upregulation kappa opioid receptor mrna in dorsal root ganglia in response to peripheral inflammation. Neuroscience 16.

Rajora, N., Boccoli, G., Burns, D., Sharma, S., Catania, A.P., Lipton, J.M. (1997). $\alpha-\mathrm{MSH}$ modulates local and circulating tumor necrosis factor- $\alpha$ in experimental brain inflammation. The Journal of Neuroscience 17 (6): 2181-2186. 
Rakanović-Todić, M., Mulabegović, N., Becic, F., Mijanovic, M., Loga-Zec, S., Kusturica, J., Burnazović-Ristić, L., Kulo, A., Kapić, E. (2011). Acute Toxicity Study of Combination of Tridecactide and Met-Enkephalin. Folia Medica 46(1):13-22.

Rang, H.P., Dale, M.M., Ritter, J.M., Moore, P.K. (2005). Pharmacology. First edition in the Serb language. Edited by Z. Todorović. Belgrade. Data status, 747-752.

Rang, H.P., Dale, M.M., Ritter, J.M., Moore, P.K. (2005). Pharmacology. First edition in the Serb language. Edited by Z. Todorović. Belgrade. Data status, 217-242.

Rittner, H.L., Brack, A., Stein, C. (2003). Pro-algesic versus analgesic actions of immune cells. Curr Opin Anaesthesiol 16: 527-533.

Rittner, H.L., Labuz, D., Schaefer, M., Mousa, S.A., Schulz, S., Schafer, M., Stein, C., Brack, A. (2006). Pain control by CXCE2 ligands through Ca2+ regulated release of opioid peptides from polyprpho nuclear cells. FASEB J

Sarkar, A., Sreenivasan, Y., Manna, S.K. (2003). $\alpha$-Melanocyte-stimulating hormone induces cell death in mast cells: involvement of NF-kB. FEBS Lett 549: 87-93.

Scholzen, T.E., Sunderkötter, C., Kalden, D.H., Brzoska, T., Fastrich, M., Fisbeck, T., Armstrong, C.A., Ansel, J.C., Luger, T.A. (2003). $\alpha$-Melanocyte stimulating hormone prevents lipopolysaccharide-induced vasculitis by down-regulating endothelial cell adhesion molecule expression. Endocrinology 144: 360-370.

Štambuk, N., Breljak, D., Križanac-Begenez, Lj. and Boranić, M. (1996). A model of metenkephalin induced alterations of the bone marrow cell proliferation. Periodicum Biologorum 96 (1): 115-118.

Štambuk, N., Brnar, V., Štambuk, V., Svoboda-Beusan, I., Rabatić, S., Mazuran, R. et al. (1997). Peptide M (Lupex(R)) immunotherapy in multiple sclerosis, optic neuritis and uveitis. Journal of Etymology 5(8-9): 448-464.

Star, A.R., Rajora, N., Huang, J., Stock, C.R., Catania, A., Lipton, M.J. (1995). Evidence of autocrine modulation of macrophage nitric oxide synthase by melanocytestimulating hormone. Proc Natl Acad Sci USA 92: 8016-8020.

Stein, C., Machelska, H., Schäfer, M. (2001). Peripheral analgesic and anti-inflammatory effects of opioids. J Rheumatol 60: 416-424.

Todić, M., Mulabegović, N., Becić, F., Kusturica, J. (2007). Subacute toxicity study of combination of adrenocorticotropine 1-13 and met-enkephalin. Med Arh. 61( 4):199202.

Tsatmali, M., Graham, A., Szatkowski, D., Ancans, J., Manning, P., McNeil, C.J., Graham A.M., Thody, A.J. (2000). $\alpha$-Melanocyte-stimulating hormone modulates nitric oxide production in melanocytes. J Invest Dermatol 114: 520-526.

Veljić, J., Marić, D., Janković, B.D. (1991). Changes of experimental allergic encephalomyelitis by methionine-enkephalin injected into lateral ventricles of the rat brain. Int J Neurosci 59(1-3): 81-89.

Vujić-Redžić, V., Dimitrijević, M., Stanojević, S., Kovačević-Jovanović, V., Miletić, T., Radulović, J. (2000). Peripheral Effects of Methionine-Enkephalin on Inflammatory Reactions and Behavior in the Rat. NeuroImmunoModulation 8: 70-77.

Wybran, J., Appelboom, T., Famaey, J.P., Govaerts, A. (1985). Suggestive evidence for receptors for morphine and methionine- enkephalin on normal human blood $\mathrm{T}$ lymphocytes. The Journal of Head and Face Pain 25: 259. 
Zagon, I.S., Wu, Y., McLaughlin, P.J. (1997). Opioid growth factor is present in human and mouse gastrointestinal tract and inhibits DNA synthesis. Am J Physiol 272 (4Pt 2): 1094-1104 


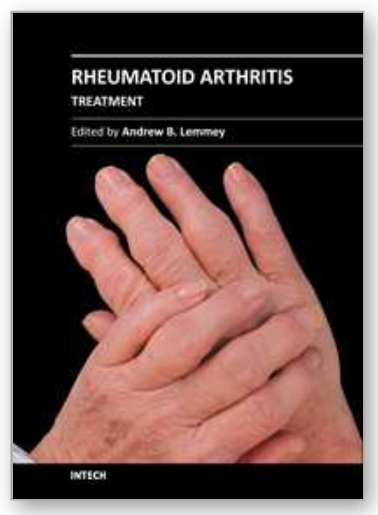

\author{
Rheumatoid Arthritis - Treatment \\ Edited by Dr. Andrew Lemmey
}

ISBN 978-953-307-850-2

Hard cover, 366 pages

Publisher InTech

Published online 18, January, 2012

Published in print edition January, 2012

The purpose of this book is to provide up-to-date, interesting, and thought-provoking perspectives on various aspects of research into current and potential treatments for rheumatoid arthritis (RA). This book features 17 chapters, with contributions from numerous countries (e.g. UK, USA, Canada, Japan, Sweden, Turkey, Bosnia and Herzegovina, Slovakia), including chapters from internationally recognized leaders in rheumatology research. It is anticipated that Rheumatoid Arthritis - Treatment will provide both a useful reference and source of potential areas of investigation for research scientists working in the field of RA and other inflammatory arthropathies.

\title{
How to reference
}

In order to correctly reference this scholarly work, feel free to copy and paste the following:

Nedžad Mulabegović, Jasna Kusturica, Maida Todić-Rakanović, Mirjana Mijanović, Fahir Bečić, Asija Začiragić, Selma Skrbo, Lejla Burnazović-Ristić, Aida Kulo and Svjetlana Loga-Zec (2012). Enkorten - A Potential Drug for the Treatment of Rheumatoid Arthritis, Rheumatoid Arthritis - Treatment, Dr. Andrew Lemmey (Ed.), ISBN: 978-953-307-850-2, InTech, Available from: http://www.intechopen.com/books/rheumatoid-arthritistreatment/enkorten-a-potential-drug-for-the-treatment-of-rheumatoid-arthritis

\section{INTECH}

open science | open minds

\section{InTech Europe}

University Campus STeP Ri

Slavka Krautzeka 83/A

51000 Rijeka, Croatia

Phone: +385 (51) 770447

Fax: +385 (51) 686166

www.intechopen.com

\section{InTech China}

Unit 405, Office Block, Hotel Equatorial Shanghai

No.65, Yan An Road (West), Shanghai, 200040, China 中国上海市延安西路65号上海国际贵都大饭店办公楼 405 单元

Phone: +86-21-62489820

Fax: $+86-21-62489821$ 
(C) 2012 The Author(s). Licensee IntechOpen. This is an open access article distributed under the terms of the Creative Commons Attribution 3.0 License, which permits unrestricted use, distribution, and reproduction in any medium, provided the original work is properly cited. 